\title{
Effect of Varying Fuel Injection Timing on Engine Performance of CNG Direct Injection in Retrofitted SI Engine
}

\author{
Rajeshkumar Jayantilal Patel ${ }^{1 *}$, Pragnesh Brahmbhatt ${ }^{2}$ \\ 1 Pacific Academy of Higher Education and Research, INDIA \\ ${ }^{2}$ Gujarat Technological University, INDIA
}

*Corresponding Author: rjpatel78@gmail.com

Citation: Patel, R. J. and Brahmbhatt, P. (2019). Effect of Varying Fuel Injection Timing on Engine Performance of CNG Direct Injection in Retrofitted SI Engine. European Journal of Sustainable Development Research, 3(3), em0089. https://doi.org/10.29333/ejosdr/5736

Published: March 21, 2019

\begin{abstract}
The study of engine performance under different fuel injection timing of a CNG direct injection engine was carried out in a retrofitted car engine. The experiment was performed on a 1297cc, 4-stroke, four cylinder SI engine having compression ratio 9. The base gasoline engine was converted into bi-fuel engine by installing both CNG port injection (CNG-PI) and CNG direct injection (CNG-DI) system in a single gasoline engine. The injection timing was varied from early injection (EI) timing at $220^{\circ}$ BTDC to a late injection (LI) timing of $120^{\circ} \mathrm{BTDC}$. The experimental study was limited by an engine speed upto $2700 \mathrm{rpm}$ due to high thermal loading at higher speed. The results indicate that, the late injection timing $120^{\circ}$ BTDC gives $10-12 \%$ higher brake power at a lower engine speed upto $1800 \mathrm{rpm}$ as the volumetric efficiency is better at a lower speed. The optimal injection timing $160^{\circ}$ BTDC produces higher performance over the entire speed range from $1200 \mathrm{rpm}$ to $2500 \mathrm{rpm}$ due to sufficient and optimum time available for preparation of CNG-air mixture. The early injection timing $210^{\circ}$ BTDC gives very good engine performance for engine speed above $2700 \mathrm{rpm}$ which accelerates better air-fuel mixing at a higher speed.
\end{abstract}

Keywords: Compressed Natural Gas (CNG), CNG-PI system, CNG-DI system, Early Injection (EI), Optimal Injection (OI)

\section{INTRODUCTION}

The use of CNG as a fuel in the transportation sector has been popular since last 10 years. It is also promoted by government for environmental concern and energy security (Aziz et al., 2010). The CNG is readily available having low density and high octane number (110-130) which produces less pollution as compared to petrol and diesel fuel (Liu et al., 2013). The CNG is a safer fuel because it can be operated at a high compression ratio and higher self ignition temperature (Jahirul et al., 2010). Most of the CNG vehicles use conventional technology as the vehicle is started with conventional fuel and then it is converted into CNG fuel. The main drawback of using $\mathrm{CNG}$ as a fuel in the engine is it gives poor performance in terms of brake power and lower thermal efficiency. Many researchers have conducted lots of research work to improve the overall engine performance using CNG as a fuel. The researchers have put their extreme effort to achieve optimal engine performance in terms of better output and least pollution (Kalam and Masjuki, 2011). As a result of that, various CNG injection technologies like single/multi point port injection (CNG-PI), sequential injection and most recent CNG direct injection (CNG-DI) have been developed (Patel and Brahmbhatt, 2014). In CNG port injection (CNG-PI), the mixture of CNG-air is formed in the common port in the air passage and then that mixture is going into the combustion chamber for burning by opening the inlet valve during suction stroke. In the sequential injection, four different gas injectors 
Table 1. Test Engine Specifications

\begin{tabular}{ll}
\hline Item & Particular \\
\hline Engine Make \& Type: & Maruti Esteem, 4-cylinder, 4-stroke water cooled petrol engine \\
\hline Bore $\times$ Stroke $(\mathrm{mm}):$ & $74 \times 55.5$ \\
\hline Displacement volume $(\mathrm{cc}):$ & 1297 \\
\hline Number of cylinder: & 4 \\
\hline Compression ratio: & 9 \\
\hline Ignition: & Spark ignition \\
\hline Loading: & Electrical dynamometer with rheostat \\
\hline
\end{tabular}

inject CNG just before the inlet valve near the inlet manifold and then mixture flowing into the combustion chamber. But in case of CNG direct injection (CNG-DI), the CNG fuel is injected directly into the cylinder by individual injector at the end of compression stroke just like a diesel engine and then it is mixed with the air in the cylinder itself. With CNG-PI system, the engine gives lower brake power and thermal efficiency due to lower volumetric efficiency (Kalam et al., 2009). The concept of CNG direct injection provides very good solution over the above difficulties but it requires certain modifications in the engine. The CNG direct injection system can increase the volumetric efficiency of engine and the engine can run with lean mixture results in a higher brake power with good thermal efficiency.

The injection timing greatly affects on the ignition characteristic of CNG-air mixture because it decides the mixture formation, turbulences and delay period. When the injection timing is varied in the CNG-DI system, the engine produces different outputs in terms of brake power and thermal efficiency (Zeng et al., 2006). The ignition and injection timing also affects on $\mathrm{CO}, \mathrm{CO}_{2}$ and $\mathrm{HC}$ concentration in the exhaust emission (Hassan et al., 2010). Generally, the mixture formation is crucial with gaseous fuel because even at a high injection velocity, it produces low fuel penetration due to less mass density (Chiodi et al., 2006). In this research work, 1-3\% error in the results may be considered due to thermal shock, calibration error and inaccurate crank angle phasing. The main objective of this research work is to investigate the effect of various injection timing on the performance and combustion behaviour of the CNG-DI engine. The engine speed was limited by $3000 \mathrm{rpm}$ due to thermal loading aspect in this work.

\section{EXPERIMENTAL PROCEDURE}

The four cylinder SI engine was modified and converted into a bi-fuel engine using various components of CNG kit. The specifications of the test engine are listed in Table 1. Here the engine was subjected to some fabrication type of work to convert it into CNG direct injection. The cylinder head was modified by drilling 3-mm size hole from upper surface of head and that hole was projected upto the respective combustion chamber throughout. The four holes of 3-mm size were drilled from the upper surfaces of cylinder head to the respective combustion chamber upto the depth of $35-\mathrm{mm}$. Then, these four holes corresponding to their combustion chambers were subjected to reaming operation for their correct size of 4-mm diameter upto 18-mm depth from the upper surfaces of cylinder head. Further these four holes were tapped for their correct size of 5-mm diameter upto 6-mm depth from the upper surfaces. The edge of brass nipple of 5-mm diameter is inserted into the 6-mm size hole for individual cylinder and all four cylinders are prepared with this type of connection. The four flexible hoses were projected from all four nipples and other ends of these flexible hoses were connected with four different specially designed gas injectors of injector rail which was located near the throttle body. The injector rail was also connected with ECU through wiring. The gas injector rail was designed for 25-50 bar injection pressure. The other components of CNG kit such as pressure reducer, CNG tank, rubber coated brass hoses, solenoid valve, etc. were properly fitted at their appropriate location in the engine. The various sensors were also installed at different location to take data from exhaust, inlet and injector rail and controlling the various parameters through ECU. The computer was equipped with ECU through switch box and the computer contain definite program for controlling the various parameters. Initially, the engine was started with petrol fuel and then it was converted into CNG mode of operation. The digital weight meter was also used to measure the weight (in gm) of CNG fuel used by engine per unit time. The engine shaft was also connected with electrical dynamometer having rheostat loading. The cooling water was continuously circulated during entire operating condition of engine.

The variation of injection timing was applied by the computer program because it was directly connected with ECU through switch box. All other data such as cooling water temperature, exhaust gas temperature, air temperature etc. were seen on the computer screen. The injection timing was varied from $210^{\circ}$ BTDC to $120^{\circ}$ BTDC and taken various observations at $210^{\circ} \mathrm{BTDC}, 160^{\circ} \mathrm{BTDC}$ and $120^{\circ} \mathrm{BTDC}$ considering early injection, optimal injection and late injection respectively. The speed of engine was varied from $1500 \mathrm{rpm}$ to $3000 \mathrm{rpm}$ with an increment of every $300 \mathrm{rpm}$ by keeping other parameters constant and the results were recorded. All the observations were taken twice to eliminate possible operating and calibration error. 


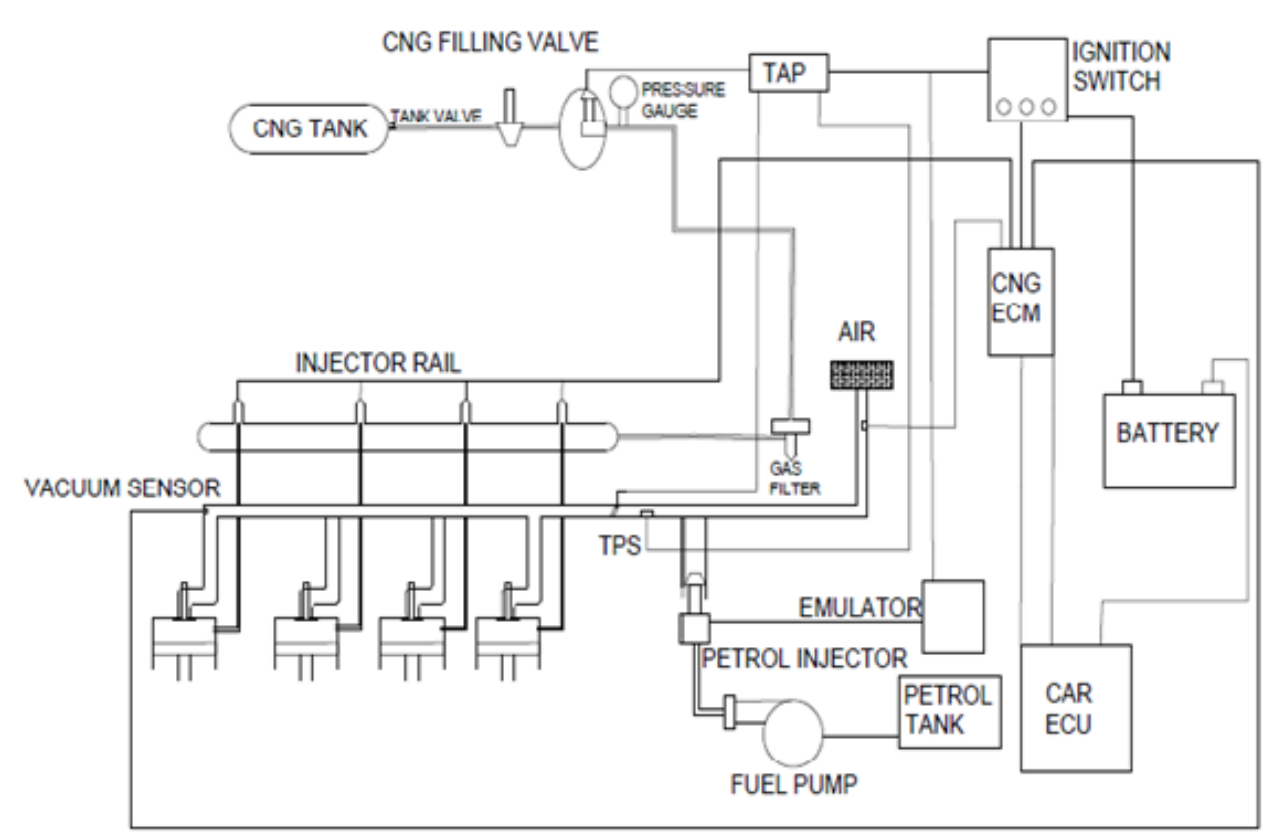

Figure 1. Schematic diagram of CNG direct injection system

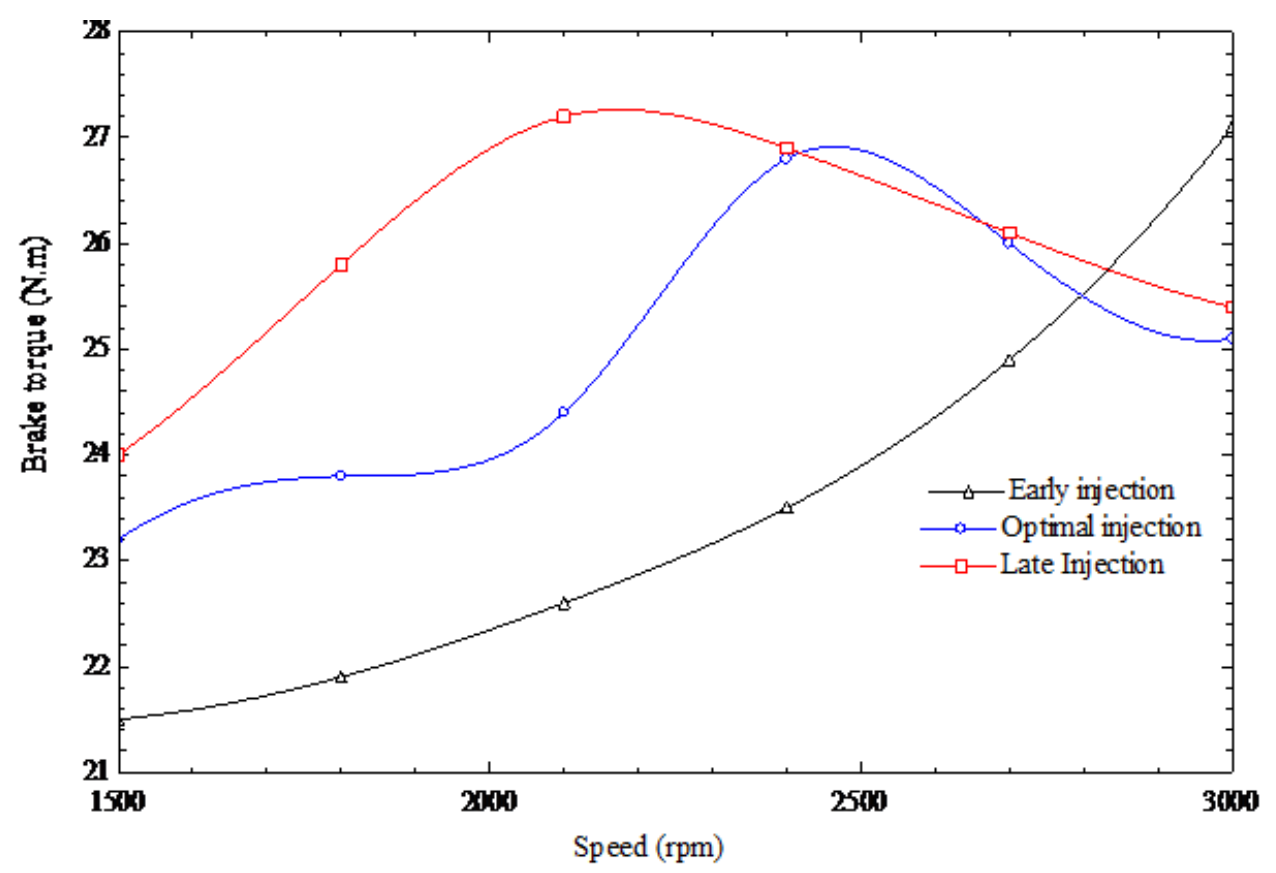

Figure 2. Variation of brake torque with engine speed

\section{RESULTS AND DISCUSSION}

The air temperature inside the laboratory was about 30-35 C during different observations. All the observations were recorded after 2-3 minutes set time required for engine operating on a particular speed and load condition.

\section{Brake Torque and Brake Power}

The effect of various injection timing on brake torque and brake power is as shown in Figure 2 and Figure 3. The engine performance is significantly affected by the volumetric efficiency at engine speed below $2700 \mathrm{rpm}$. In this speed range below 2100rpm, the late injection timing $120^{\circ}$ BTDC gives $10-12 \%$ higher torque output as compared to early injection and optimal injection. The optimal timing $160^{\circ} \mathrm{BTDC}$ has the combined effect of high volumetric efficiency and sufficient mixing time that provides $8-10 \%$ higher torque at speed range from $2300 \mathrm{rpm}$ to $2800 \mathrm{rpm}$. The injection timing has less effect on the volumetric efficiency above $3000 \mathrm{rpm}$ as less time available for suction stroke to suck the air. As the injection timing is retarded (towards the late injection side), the volumetric efficiency is in increasing trend. 


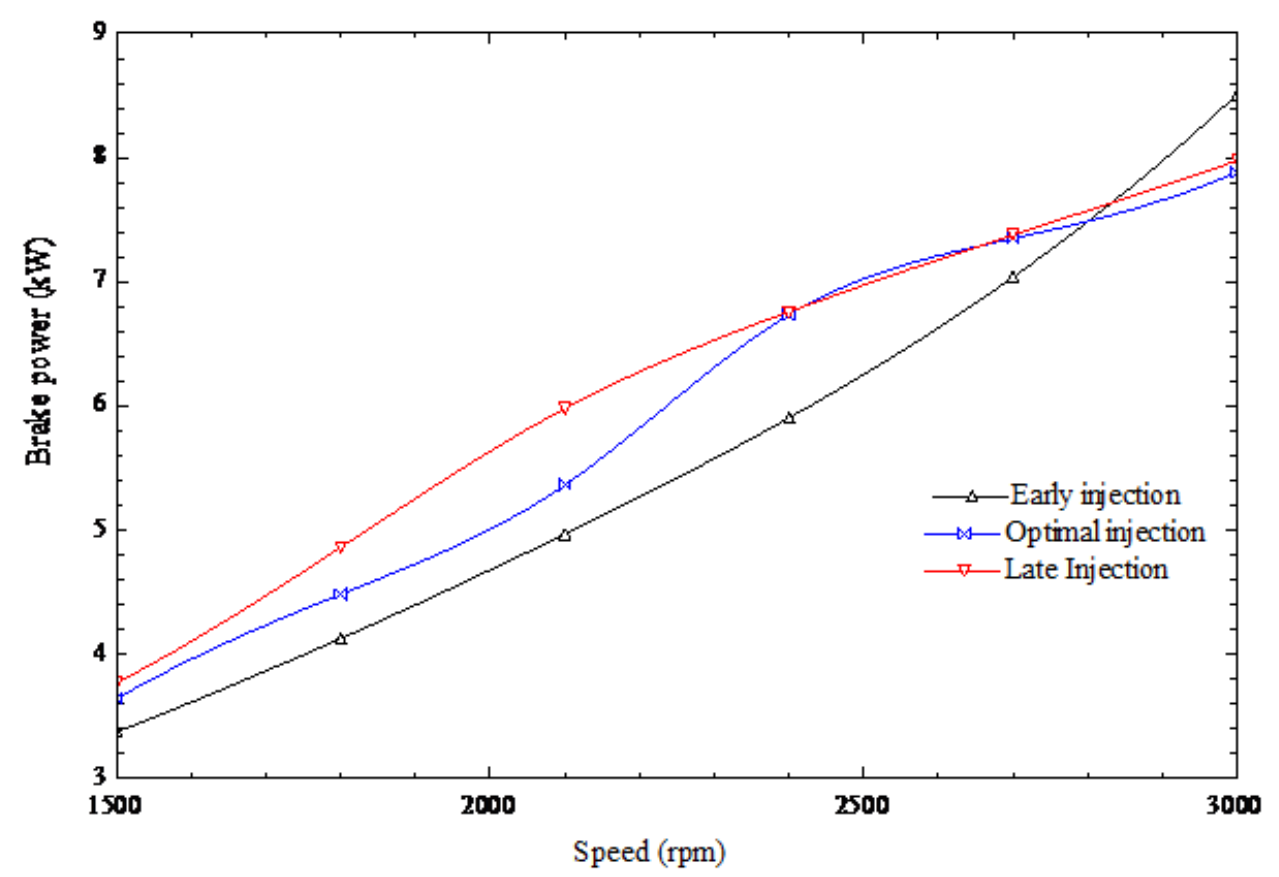

Figure 3. Variation of brake power with engine speed

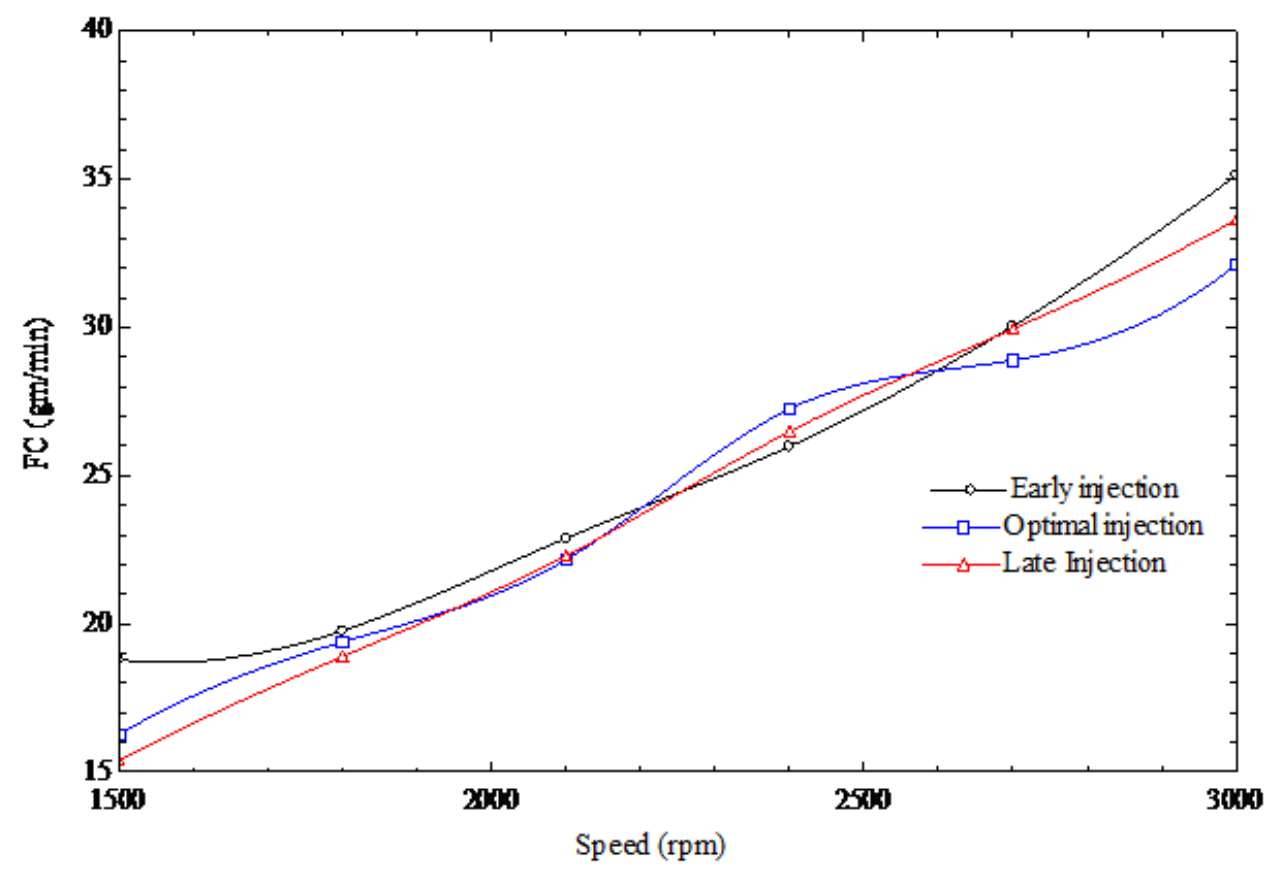

Figure 4. Variation of fuel consumption with engine speed

\section{Fuel Consumption}

Figure 4 shows engine speed versus fuel consumption at different injection timing. The late injection timing $120^{\circ}$ BTDC gives lowest fuel consumption upto $2100 \mathrm{rpm}$ due to higher volumetric efficiency. The optimal timing $160^{\circ}$ BTDC shows lowest fuel consumption at $2100 \mathrm{rpm}$ and also lower among all between $2700 \mathrm{rpm}$ and 3000 $\mathrm{rpm}$ as the speed is increased, sufficient time is required for mixture preparation.

\section{Brake Specific Fuel Consumption}

Figure 5 shows engine speed versus brake specific fuel consumption at different injection timing. The late injection timing $120^{\circ}$ BTDC gives lowest SFC upto $2400 \mathrm{rpm}$ and then after the optimal injection timing $160^{\circ}$ BTDC shows lower SFC among all between $2700 \mathrm{rpm}$ and $3000 \mathrm{rpm}$. 


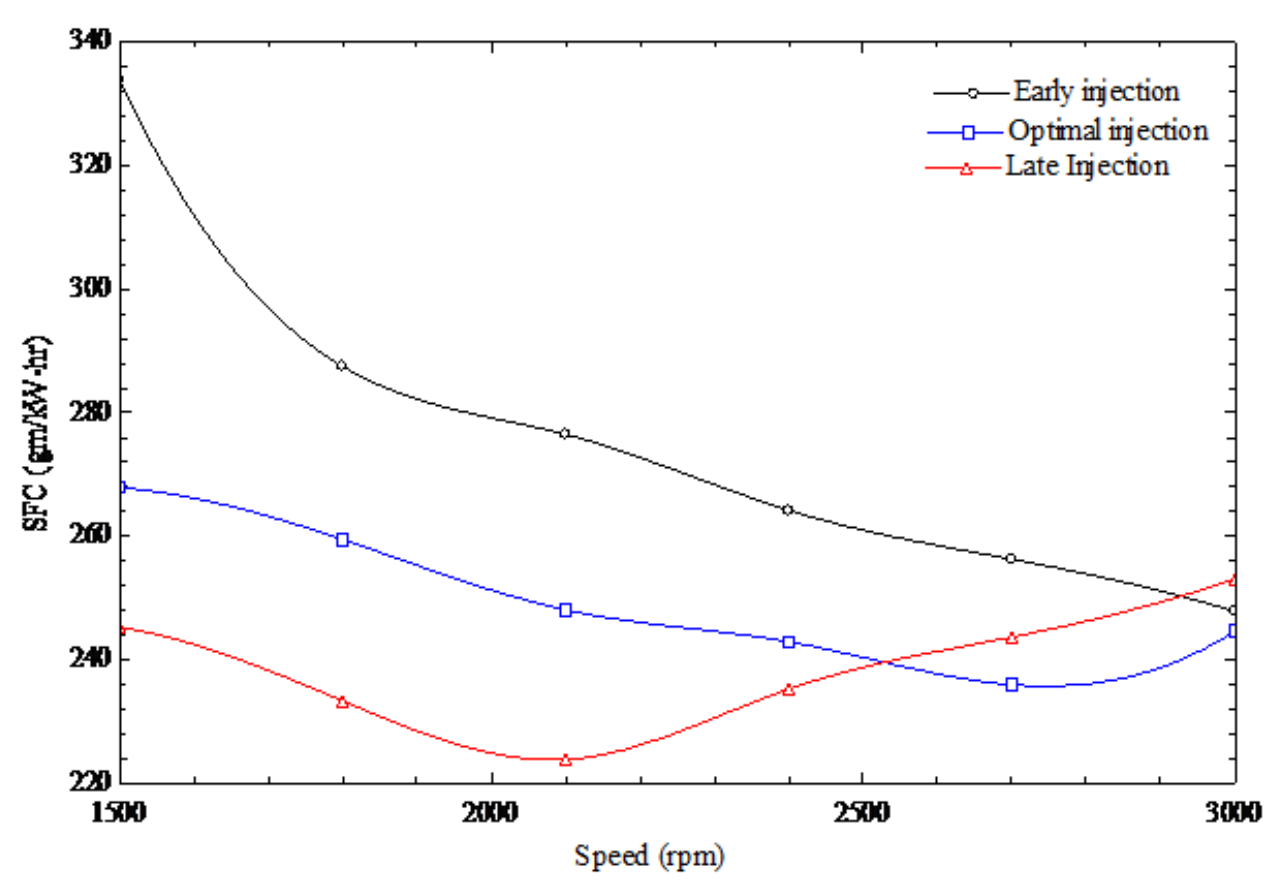

Figure 5. Variation of specific fuel consumption with engine speed

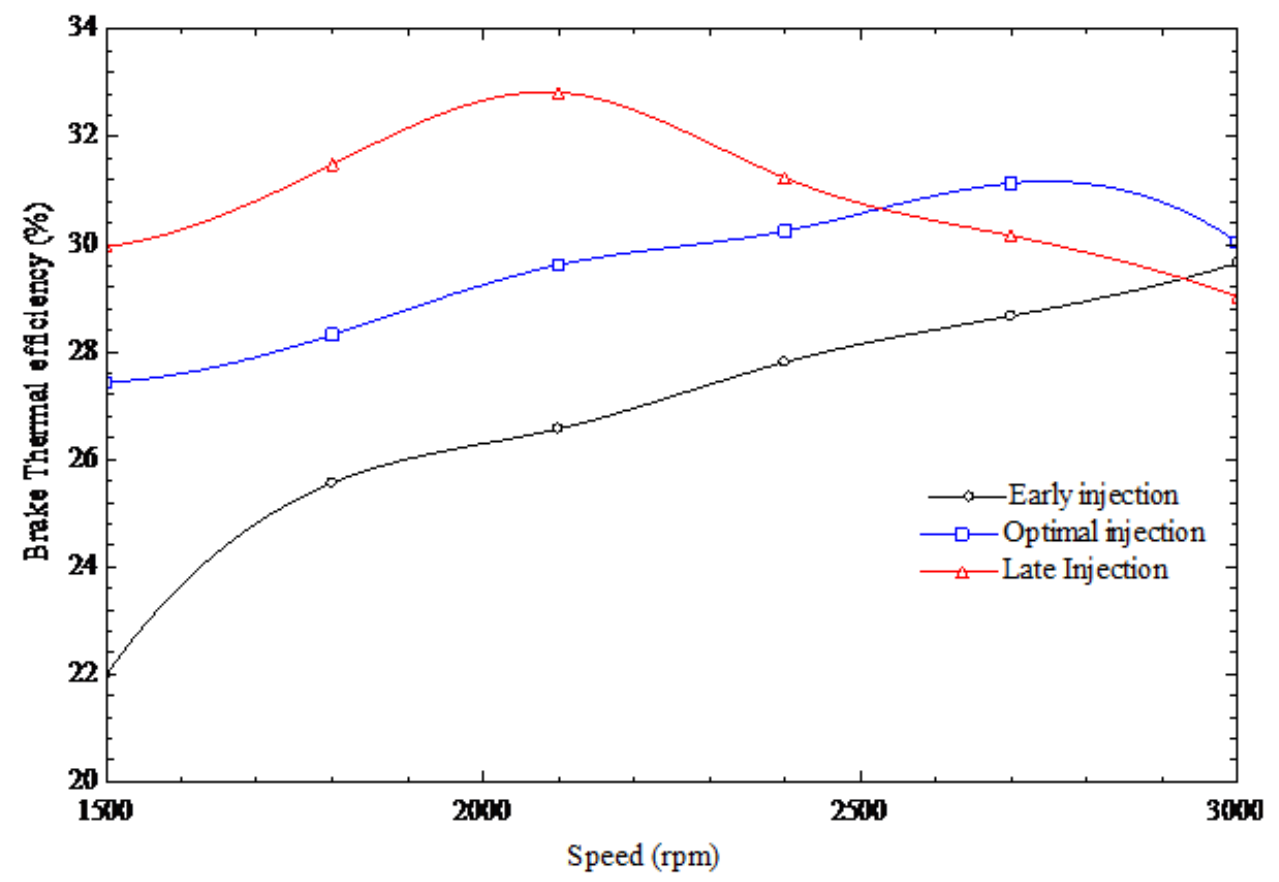

Figure 6. Variation of brake thermal efficiency with engine speed

\section{Brake Thermal Efficiency}

Figure 6 shows engine speed versus brake thermal efficiency at different injection timing. The late injection timing $120^{\circ}$ BTDC produces highest brake thermal efficiency among all three upto $2400 \mathrm{rpm}$ due to higher volumetric efficiency. The optimal injection timing $160^{\circ}$ BTDC shows higher brake thermal efficiency above 2700 rpm due to more scope of expansion work at a higher speed.

\section{CONCLUSION}

The following conclusions may be drawn from the obtained observations by experimental work:

i. The volumetric efficiency decreased with the advancement of CNG injection timing in a CNG direct injection engine. 
ii. The late injection timing $120^{\circ}$ BTDC gives $10-12 \%$ higher brake torque and brake power at engine speed below $2100 \mathrm{rpm}$. At this stage, the heat release rate is also higher and faster due to $90 \%$ of the completion of combustion process. The late injection timing also shows lowest BSFC upto the speed $2400 \mathrm{rpm}$.

iii. The optimal injection timing $160^{\circ}$ BTDC provides $8-10 \%$ higher brake power and lower BSFC in the speed range from $2400 \mathrm{rpm}$ to $2700 \mathrm{rpm}$ than the early injection timing.

iv. The early injection timing $210^{\circ}$ BTDC gives better torque characteristics and high brake power above $2800 \mathrm{rpm}$ speed. This may be achieved due to less availability of time for complete mixing of CNG and air at a higher speed

\section{NOMENCLATURE}

$\begin{array}{ll}\text { CNG } & \text { Compressed Natural Gas } \\ \text { CNG-PI } & \text { CNG Port Injection } \\ \text { CNG-DI } & \text { CNG Direct Injection } \\ \text { BTDC } & \text { Before Top Dead Centre } \\ \text { EI } & \text { Early Injection } \\ \text { OI } & \text { Optimal Injection } \\ \text { LI } & \text { Late Injection } \\ \text { BP } & \text { Brake Power } \\ \text { FC } & \text { Fuel Consumption } \\ \text { SFC } & \text { Specific Fuel Consumption } \\ \text { CV } & \text { Calorific Value }\end{array}$

\section{REFERENCES}

Aziz, A., Rashid, A., Firmansyah, F., Shahzad, R. and Shahzad, R. (2010). Combustion analysis of a CNG direct injection spark ignition engine. International Journal of Automotive and Mechanical Engineering (IJAME), 2, 157-170. https://doi.org/10.15282/ijame.2.2010.5.0013

Chiodi, M., Berner, H. J. and Bargende, M. (2006). Investigation on different injection strategies in a direct-injected turbocharged CNG-engine (No. 2006-01-3000). SAE Technical Paper. https://doi.org/10.4271/2006-01-3000

Hassan, M. K., Aris, I., Mahmod, S. and Sidek, R. (2010). Influence of injection and ignition of CNG fuelled direct injection engine at constant speed. Australian Journal of Basic and Applied Sciences, 4(10), 4870-79.

Jahirul, M. I., Masjuki, H. H., Saidur, R., Kalam, M. A., Jayed, M. H. and Wazed, M. A. (2010). Comparative engine performance and emission analysis of CNG and gasoline in a retrofitted car engine. Applied Thermal Engineering, 30(14), 2219-2226. https:// doi.org/10.1016/j.applthermaleng.2010.05.037

Kalam, M. A., Masjuki, H. H., Mahlia, T. M. I., Fuad, M. A., Halim, K., Ishak, A., ... and Shahrir, A. (2009). Experimental test of a new compressed natural gas engine with direct injection. Energy Fuels, 23(10), 4981-4987. https://doi.org/10.1021/ ef8011382

Kalam, M. A. and Masjuki, H. H. (2011). An experimental investigation of high performance natural gas engine with direct injection. Energy, 36(5), 3563-3571. https://doi.org/10.1016/j.energy.2011.03.066

Liu, Y., Yeom, J. and Chung, S. (2013). A study of spray development and combustion propagation processes of spark-ignited direct injection (SIDI) compressed natural gas (CNG). Mathematical and computer modelling, 57(1), 228-244. https://doi.org/10.1016/i.mcm.2011.06.035

Patel, R. J. and Brahmbhatt, P. (2014). A Technical Review of Performance of CNG Direct Injection in Spark Ignition Engine. International Journal of Advance Engineering and Research Development (IJAERD), 1(11), e-ISSN: 2348-4470.

Zeng, K., Huang, Z., Liu, B., Liu, L., Jiang, D., Ren, Y. and Wang, J. (2006). Combustion characteristics of a directinjection natural gas engine under various fuel injection timings. Applied thermal engineering, 26(8), 806-813. https://doi.org/10.1016/j.applthermaleng.2005.10.011 